\title{
News
}

\section{Weighing in on the future of gene patenting}

1 n March 2010, Judge Robert Sweet of the Southern District of New York issued a ruling against Myriad Genetics, holder of exclusive patents on the breast cancer genes $B R C A 1$ and BRCA2, indicating that genes should not be eligible for patent protection. In October, the Justice Department surprised policy watchers by filing an amicus brief in support of the ruling. James Evans (Figure 1), who chaired a task force on gene patents and licensing practices for the Department of Health and Human Services (HHS), recently spoke to the JCI about gene patents and the likely impact of this ruling.

JCI: About $20 \%$ of human genes are currently under patent protection. How does that affect researchers who want to work on those genes and gene products?

Evans: From a clinical standpoint, it is very restrictive. The genes under patent and exclusive license, like $B R C A 1 / 2$, can only be analyzed by a single laboratory. For basic research, in practice, most holders of gene patents have not vigorously enforced their claim, even though in principle they could certainly keep anyone from doing research on a gene that they own a patent on. It's often been cited by proponents of gene patents that there has been little patent-related restriction of basic research. But the reason for that is that patent holders have often chosen not to enforce their rights, and that researchers have generally ignored patents, which is hardly a ringing endorsement of the system.

JCI: How did this most recent ruling affect those who currently hold gene patents?

Evans: In tangible, practical terms, the ruling by Judge Sweet doesn't do anything, because it only pertains to the southern district of New York. However, there are more intangible effects. It was the first time that a federal judge had ruled on this issue, and his ruling that genes are not eligible for patent protection sent shock waves through the intellectual property community. Just having done that, regardless of the fact that it only holds in his district, is significant. This decision is being appealed, so the impact could be profound if it is upheld by either the Court of Appeals or the Supreme Court.

JCI: The Department of Justice filed an amicus brief asserting that isolated DNA is a product of nature and should not be patentable, but it supports the right of corporations to patent manipulated genes. Do you see a difference between isolated DNA and manipulated DNA in terms of patentability? Evans: The DOJ brief drew a very bright and logical line, saying that a natural gene, which evolved over millions of years, is hardly patent eligible. It's ineligible for patent for the same reason that gold, or sunshine, or a beetle that you find under a rock would be ineligible. It's not an invention, no matter how hard or how useful it was to isolate. They drew a line between that and a manipu-

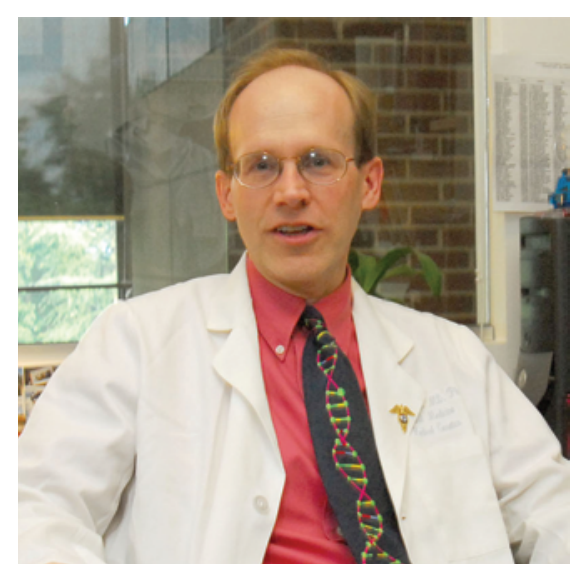

\section{Figure 1}

James Evans, MD, PhD, is a medical geneticist at the University of North Carolina School of Medicine. Photo credit: Karen Tam (The New York Times).

lated DNA sequence. I think that's interesting, and a useful starting place, but I think that Judge Sweet actually got closer to the truth when he made the distinction in his ruling about what the gene does being the important factor. A gene in the cell transmits information, and if the information that it transmits in vivo is the same as the information that it transmits in the test tube, then in isolating it you really haven't done anything that should be eligible for patenting.

JCI: Do you think cell lines - including human stem cell lines or induced pluripotent stem cells - should be patentable?

Evans: Claiming a patent on a manipulated cell line is very different from claiming a patent on a gene. I'm not a lawyer, but I would think that an induced pluripotent stem cell line that was created by people - engineered with genes that impart information for the cell to do something new - would be very reasonable to patent.

JCI: If an actual gene sequence shouldn't be patentable, should a genetic test?

Evans: I feel strongly that claiming patent protection of a genetic test that relies on analysis of a naturally occurring gene makes no sense. Not only that, but it's demonstrably harmful to patients, researchers, and, for that matter, the market. To be tested for cystic fibrosis or Huntington disease - genes that are not under patent - you can go to any of about 60 laboratories to have that testing done. Those laboratories vie for your business by trying to develop innovative methods for testing, better quality, or better service. On the other hand, there is just a single laboratory you can go to for $B R C A 1 / 2$ testing. That laboratory is under no pressure to improve its service, because there's no competition.

JCI: Are you concerned that disallowing gene patents would decrease investment in the research and development of gene products and genetic testing?

Evans: Patent protection is a tricky business - if you do it too far upstream, you squelch creativity; if you do it too far downstream, it does no good. I think patents at the level of the gene are clearly too far upstream. The pro-patent people have a stronger argument in the realm of therapeutics, since they may need incentives to promote research and development. My counter to that is that therapeutics rely upon a welter of patentable facets, and it's hard to imagine that therapeutics would rely upon patenting of the gene itself. By not patenting the gene, you encourage more investigators to work on therapeutics, which would then be patented because of the truly inventive things they came up with. The patent system exists for a single purpose: to promote the progress of science and the useful arts. It is designed to promote progress, to promote activity, to open up investigations. The idea of restricting research with patents is profoundly antithetical to the very purpose of the patent system. Therefore, I feel that patents that either restrict or potentially restrict research are harmful. One of the recommendations that our task force made to the Secretary of HHS was that there be a broad research use exemption from infringements regarding gene patents. What we advocate is that researchers should be free to use genes in their research, without fear of infringement. If they're allowed to do that, everyone wins.

\section{Kathryn Claiborn}

